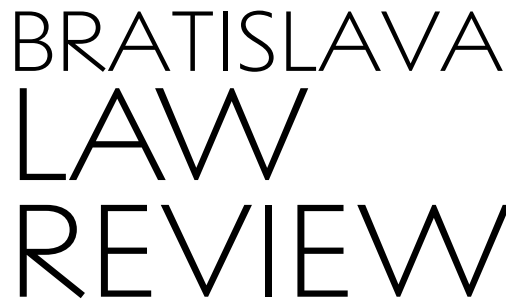

PUBLISHED BY

THE FACULTY OF LAW, COMENIUS UNIVERSITY IN BRATISLAVA

\title{
IMPROVEMENT OF EFFECTIVENESS OF LEGAL REGULATION OF PUBLIC PROCUREMENT AND ITS APPLICATION WITHIN EU LAW CONTEXT (BRATISLAVA, 25 NOVEMBER AND 3 DECEMBER 2020) /
} Adam Máčaj, Daniel Zigo

\author{
Mgr. Adam Máčaj \\ Comenius University in Bratislava, \\ Faculty of Law, Institute of European \\ Law; Šafárikovo nám. 6; 81800 \\ Bratislava, Slovakia \\ adam.macaj@flaw.uniba.sk \\ ORCID: 0000-0002-3086-8025
}

\section{Mgr. Daniel Zigo}

Comenius University in Bratislava, Faculty of Law, Department of Commercial Law and Economic Law; Šafárikovo nám. 6; 81800 Bratislava, Slovakia

daniel.zigo@flaw.uniba.sk

ORCID: 0000-0003-2414-3471

This report was prepared as part of the research project APVV-17-0641 "Improvement of effectiveness of legal regulation of public procurement and its application within EU law context".

Submitted : 14 December 2020 Published: 31 December 2020

\section{Suggested citation:}

Máčaj, A., Zigo, D. (2020). Improvement of effectiveness of legal regulation of public procurement and its application within EU law context (Bratislava, 25 November and 3 December 2020).

Bratislava Law Review, 4(2), 205-210

https://doi.org/10.46282/blr.2020.4.2.218

Comenius University in Bratislava held two scientific conferences in November and December 2020, dealing with contemporary topics in public procurement and its regulation on national and European level. Due to the ongoing restrictions related to the SARS-CoV-2 pandemic, both events were held online, nevertheless they attracted a plethora of participants of both academic and professional backgrounds. Both conferences were held as part of a research project APVV-17-0641 "Improvement of effectiveness of legal regulation of public procurement and its application within EU law context", but focused on a broad range of issues with cross-cutting implications, 
including independence and accountability of decision-making authorities, effectiveness of sanctions, and alternatives thereto.

The first conference, "Independence, Accountability, and Protection of Public Interest in Market Regulation and Public Procurement", took place on Wednesday, 25 November 2020 at 1:00 p.m. The keynote speech was delivered by JUDr. Miroslav Hlivák, PhD., LLM, president of the Office for Public Procurement of Slovakia, followed by doc. JUDr. Ing. Ondrej Blažo, PhD., director of the Institute of European Law at Faculty of Law of the Comenius University in Bratislava. The main highlights of the conference opening were especially the reiterated need for maintaining independence of market regulatory authorities on a variety of grounds, such as the requirements stemming from EU law, the independence as indispensable feature to ensure functioning of responsible authorities, and the broader implications of independence of public bodies. On the other hand, implications pertaining to accountability and democratic control of the very same institutions were also considered to be essential in contemporary discourse.

Afterwards, JUDr. Zuzana Šabová, PhD. and Assoc. Prof. Ing. Daniela Zemanovičová, CSc. brought useful insight into the development and newest proposed changes in the Anti-monopoly Office of Slovakia, which are likely to impact also the political independence and impartiality from external pressures. Describing the historical changes to nominations and appointments into the leading positions of the Antimonopoly Office, the speakers found that variety of factors are liable to undermine objective and subjective independence of regulatory bodies, including but not limited to political appointees being granted leading positions in the institutions, or confidentiality of candidates proposed for the position.

JUDr. Mária T. Patakyová, PhD. from Institute of European Law at Faculty of Law of the Comenius University in Bratislava devoted her presentation to assessment of ongoing transposition of Directive (EU) 2019/1 in Slovakia that similarly impacts especially institutional position of Anti-monopoly Office. The main features of the proposed changes deal with explicit formulation of independence and impartiality in the statutory provisions, or more precise delimitation of bodies entitled to submit proposals for appointment of president of the Anti-monopoly Office to the government. On the other hand, the appointment by the government remains deficient in transparency, and proposed changes in cooldown period of leading representatives of the Anti-monopoly Office are similarly unsatisfactory, especially as they seem to lack enforcement mechanism.

Ing. Boris Gregor, vice-president of the Anti-monopoly Office, noted in the discussion that within the office, an independent proposal of legislative amendments needed to deal with position, independence, and tasks of the Anti-monopoly Office, providing for a comprehensive transposition of Directive (EU) 2019/1 from the view of professionals working directly in the institution. Their own efforts were, however, halted by difficulties in accessibility and transparency of similar regulations in other EU Member States, hampering comparative analysis or an assessment of best practices. Similarly, president of the Office for Public Procurement concurred that he considers independence of control and regulatory authorities as one of essential features in a rule of law, and praised attempts of the European Commission to strengthen this independence. He pointed out that on the basis of this impetus, Office for Public Procurement was drafting its own proposed amendments to legislation for over a year, in an attempt to balance interests of contracting authorities, as well as tenderers, and broader consideration of public interest. In their proposal, this balance is maintained through an ambitious strengthening of institutional independence, by formulating strict requirements for 
candidates for presidency, or institutional balance in appointments to the Council of the Office for Public Procurement, as an appellate body.

Assoc. Prof. JUDr. Katarína Kalesná, CSc. from Institute of European Law at Faculty of Law of the Comenius University in Bratislava dealt with professionalization of public procurement in her speech. She considered especially its modernization and centralization through education in a variety of topics pertinent to public procurement, such as fundamental principles of public procurement, intellectual property, or case-law related thereto. She also pointed out the close relationship between competition law and public procurement, suggesting that absence of the former in education of responsible stakeholders may prove to be detrimental to the latter.

Prof. JUDr. PhDr. Miroslav Slaštan, PhD. from Department of International Law and International Relations at Faculty of Law of the Comenius University in Bratislava focused on the issue of EU legislative instruments in the area of public procurement and their legal effects. He pointed out the problem that frequently, monitoring, decisions, and revision are undertaken by the same institutions within the Member States.

JUDr. Juraj Tkáč from Comenius University in Bratislava, Faculty of Law assessed similarly revision procedures in public procurement. He pointed out that in spite of the announced changes, no draft of actual statutory text to be the basis of the amendments has been presented thus far. This hinders public discussion about the proposals, as well as limits the experts from academia and practice to analyse the appropriateness or necessity, and benefits of the proposed changes. He cautioned that the proposed changes, including those dealing with tenders below threshold values, may eventually come into conflict with EU law, as it nevertheless covers such tenders crossborder, and limited discussion of the impact the changes may have is therefore not desirable.

The second online conference, "Administrative Sanctions and Alternative Approaches to Solutions of Public Procurement Rule Infringements", took place on 3 December 2020 and, following up on various issues from the previous conference, elaborated especially on ways of adopting preventive, support, and sanction mechanisms in public procurement, and how to mitigate the amount and scale of infringements in public procurement.

The conference was once again opened both by JUDr. Miroslav Hlivák, PhD., LLM, president of the Office for Public Procurement of Slovakia, and oc. JUDr. Ing. Ondrej Blažo, PhD., director of the Institute of European Law at Faculty of Law of the Comenius University in Bratislava. President Hlivák once again appreciably noted the topic of the conference focused on questions that are subject to review in the proposed legislative changes. He reiterated the necessity to change the public perception of the Office for Public Procurement's activities to emphasize other approaches of their activities than sanctions. Director Blažo focused on quantification of fines imposed for infringements of public procurement rules in his speech. The aim of his research was to establish the amount of fines imposed by the Office for Public Procurement to various types of contracting authorities in Slovakia, and disaggregate the amount and height of fines on the basis of underlying infringement. The results established that most common infringement in public procurement is omission to act in accordance with procedure under the Public Procurement Act, and similarly this infringement is most severely punished, by fines comparatively higher to other infringements. The second most common infringement was violation of basic principles of public procurement, and most often, the responsible contracting authorities were either central government bodies, or regional self-administering entities. The research then focused on inquiring whether contracting authorities considered the sanctions and took steps to prevent similar infringements in the future, e.g. by claiming damages from persons responsible, or 
adopting compliance measure pro futuro. Overall, out of 241 cases, only 146 contracting authorities adopted similar measures, posing therefore the question whether these, in conjunction with alternative sanctions, should not be considered more viable in relation to height of the fines by themselves.

The ensuing discussion dealt with a broad range of related issues, including the possibility to mitigate the fine imposed by $50 \%$, which has been proven to bring preventive effects on contracting authorities, and proposals on part of the Office for Public Procurement consider expansion of situations where such mitigation of fines could be considered. The issue that arose in the course of comments by participants was also whether strict stipulation of lowest and highest applicable fine is the appropriate limitation, and whether proportion of the actual value of the tender should not be considered. In the view of the Office for Public Procurement, the current legislation is easier in application, although as doc. JUDr. Matej Horvat, PhD. pointed out, courts in Czechia already require these fines to avoid being destructive for the companies concerned. He also questioned what alternative approaches to pecuniary sanctions could be considered if public procurement itself concerns predominantly funding and public finances.

JUDr. Hynek Brom from Charles University in Prague dealt with purpose of the fines and alternative concepts of sanctioning infringements in public procurement, e. $\mathrm{g}$. through changes especially in procedural rules, where more initiative would be required from the parties, as compared to current burden of investigation being placed upon Office for Public Procurement. This way, the sanction in form of the fine would be supplemented also by official finding as to the entitlements of respective parties and lawfulness of their claims.

Assoc. Prof. JUDr. Peter Lukáčka, PhD. from Department of Commercial Law and Economic Law at Faculty of Law of the Comenius University in Bratislava, with JUDr. Peter Kubolek from Office for Public Procurement, delivered their speech, dealing with prospective future introduction of prior assessment of contractual terms in public procurement, with the purpose of broadening the scope of monitoring from Office for Public Procurement prior to conclusion of a contract, to include assessment of compatibility of contractual terms not only with rules of public procurement, but also other mandatory norms, infringement of which can restrict competition, irresponsibly allocate public funding, or even annulment of tender. Alternative to sanctioning such infringement in form of prior assessment would therefore bring effective way to monitor infringements before they occur.

The final presentation was held by Mgr. Daniel Zigo from Department of Commercial Law and Economic Law at Faculty of Law of the Comenius University in Bratislava, and dealt with civil liability of public officers for damages caused when managing public funds. Assessing the historical attempts to enshrine such liability in Slovakia, and current legislative proposals, the author found that even in absence of any legislative amendments, which are likely to be controversial and intensively debated, the law offers a variety of measures to invoke civil liability of public officials even nowadays. The real issue is very rare commencement of the applicable proceedings. On the other hand, the ongoing proposals provide for conferring competence on specific state bodies to enforce the civil liability against public officials, and enshrine obligation of public officials to act with due diligence explicitly in the legislative text. Nevertheless, it remains questionable whether these novelties in fact increase the likelihood of public officials being called to account for their failures in securing appropriate utilization of public finances. 
The conferences brought new life into ongoing debates concerning public procurement and efficient administration of public finances, issues that are of everincreasing importance across the EU. Further development in this area is therefore certainly expected, providing yet other incentives for extensive academic research, and cooperation of academia with professionals and state authorities in the future. 
